\title{
STOCK-FLOW CONSISTENT MODELING OF DEFAULT EVENTS SEQUENCE IN A CLOSED ECONOMY
}

\author{
Ihor Voloshyn ${ }^{1}$ \\ National Bank of Ukraine \\ Email: Ihor_Voloshyn@bank.gov.ua
}

\begin{abstract}
By sequentially examining the full chain of events starting from the default of firms through the fire-sale of goods towards the write-offs of bad loans, we develop a new matrix of financial transactions. This matrix is incorporated into the transactions-flows matrix of the closed economy consisting of households, firms, and banks. On the basis of the balance sheet and transactionsflows matrices, this study further constructs a stock-flow consistent model of the closed economy. We also provide the results of a numerical simulation and argue that our model allows studying how such key parameters as the probability of default, the rate of fire-sales (new injected parameter), the recovery rate, and interest rates on loans and deposits affect the performance of banks and firms, observing economic dynamics in time.
\end{abstract}

\section{JEL Codes: E16, E17, E21, E23, G21}

Keywords: closed economy, stock-flow consistent framework, probability of default, fire-sales, write-offs

\section{INTRODUCTION}

Goodhart (2008) wrote that "although many formal macroeconomic models (implicitly) employ an assumption of a defaultfree system in their so-called transversality assumption, it is not, alas, a characteristic of the real world. Indeed, the probability of default (PD) is a key concept in any analysis of financial fragility... If economic theory and formal models are to provide analytical support and guidance for issues relating to financial fragility, they must make the modeling of default a central feature of their work".

White (2010) stated that "the prevailing macroeconomic frameworks simply allowed no room for crises of the sort we are currently experiencing... Absent an analytical framework that included the possibility of crises and deep economic slumps, it is not surprising that the crisis was not commonly anticipated. Nor is it surprising that no policy efforts were made to prevent the crisis from happening".

After them, Caiani et al. (2016) argue that "the crisis cast serious doubts on the plausibility of standard macroeconomic models ... and their ability to provide effective policy advices to prevent the occurrence of large-scale economic turmoils, and to tackle their consequences".

All this suggests the need for the development of alternative approaches to macroeconomic modeling in order to incorporate the possibility of default into the core of the analysis (Goodhart et al., 2008, 2011; Caiani et al., 2016; Stellian \& Buitrago, 2014).

This study aims to track the full sequence of events in a closed economy as a whole and to develop a corresponding nonequilibrium, dynamic mathematical model. To avoid accounting errors and unacceptable implications that may be unnoticed, and therefore ignored, we will methodologically draw on the stock-flow consistent (SFC) approach (Godley, 1996). It should be noted that the resulting mathematical model can be used in various macroeconomic models not necessarily based on the SFC framework, for instance, into Dynamic System Models (Yamaguchi, 2013).

The remainder of the paper is organized as follows. A brief review of the literature about macroeconomic models incorporating defaults events sequence in an economy is given in Section II. Section III presents the mathematical model of an economy with firms' defaults based on the stock-flow consistent framework. Model dynamics are studied in Section IV in which we report the simulation results. Section V concludes.

\footnotetext{
${ }^{1}$ Acknowledgments. The author is very grateful to an anonymous reviewer for valuable comments and fruitful suggestions for improving the paper.
} 


\section{BRIEF LITERATURE REVIEW}

In response to the recent world crisis, various economic schools have developed new macroeconomic models that incorporate defaults into the economy. Thus, the dynamic stochastic general equilibrium (DSGE) model developed by Benes et al. (2014) makes a connection between defaults on loans and macroeconomic variables. Their model allows simulating productivity growth, changes in the riskiness of bank borrowers, deviations of asset prices, shocks to bank equity, etc. Authors argued that "excessively large and risky loans can impair balance sheets and sow the seeds of a financial crisis". The aim of their work was to investigate "an optimal equilibrium phenomenon resulting from the interactions between loan contracts, endogenous loan losses and regulation". But, the question of how the rate of fire-sales affects the coverage of losses remains unexplored. Additionally, real economical processes are non-equilibrium.

The Agent-Based model "usually assumes that new firms enter the market to replace defaulted ones with a given stock of capital and liquid assets. This assumption is implicitly imposing an exogenous positive shock on the model dynamics which counteracts the negative endogenous shock related to the firm's default" (Caiani et al., 2016).

Combining the Agent-Based and Stock Flow Consistent approaches (AB-SFC), Caiani et al. (2016) suggested a model that takes into consideration the defaults of economical agents. They considered more fully the chain of events caused by defaults including the fire-sales of assets to recover the bad loans of firms. For simplicity reasons, they assumed that defaulted firms and banks to be bailed in by households and depositors in order to maintain the number of firms and banks constant. Dynamics of inventories has not been investigated.

Another scientific school led by Godley and Lavoie (2007) proposed a macroeconomic model with defaults under the stockflow consistent framework. Two special matrices of a balance sheet and transactions based on the quadruple entry principle allow careful consideration of the impact of defaults on both stocks and flows. However, they did not consider the events of fire-sale of assets. Also, the rate of fire-sales is a key indicator as to how quickly banks can recover losses on bad loans due to firms' defaults. This crucial chain determines the redistribution of income and losses between sectors of the economy.

\section{MODEL OF ECONOMY WITH DEFAULT OF FIRMS}

We consider a closed cashless economy that consists of households, production firms that may go into default, and banks.

In order not to obscure the view of idea with a number of details, we proposed the next assumptions. Firms have no fixed capital. The only means of production is labor. Both firms and banks have no equities. Therefore, they pay out no dividends to households. Households take no loans. Only the households consume goods produced by firms. Since this economy does not include government, both banks and firms do not pay taxes.

To start production, the firms borrow loans from banks, hire workers of households, and pay them wage bill. Further, firms produce goods and sell them to households. Thus, workers of households spend their wages to buy goods. Firms pay interest on their good (performing) loans to banks and receive interest on their deposits from banks. Households receive interest on their deposits from banks (Graziani, 2003; Keen, 2010; Voloshyn I. and Voloshyn M., 2016).

In view of the above-described model, the stylized balance sheet of the economy developed by Godley and Lavoie (2007) looks like:

Table 1. The stylized balance sheet of the economy (Godley and Lavoie, 2007)

\begin{tabular}{|c|c|c|c|c|}
\hline & Households & Firms & Banks & $\Sigma$ \\
\hline Inventories & & $+\mathrm{IN}$ & $+\mathrm{IN}$ \\
\hline Deposits & $+\mathrm{D}_{\mathrm{h}}$ & $+\mathrm{D}_{\mathrm{f}}$ & $-\mathrm{D}_{\mathrm{h}}-\mathrm{D}_{\mathrm{f}}$ & $\mathbf{0}$ \\
\hline Loans & & $-\mathrm{L}_{\mathrm{f}}$ & $\mathrm{L}_{\mathrm{f}}$ & $\mathbf{0}$ \\
\hline Net wealth & $-\mathrm{V}_{\mathrm{h}}$ & $-\mathrm{V}_{\mathrm{f}}$ & $-\mathrm{V}_{\mathrm{b}}$ & $-\mathrm{IN}$ \\
\hline$\Sigma$ & $\mathbf{0}$ & $\mathbf{0}$ & $\mathbf{0}$ & $\mathbf{0}$ \\
\hline
\end{tabular}

It is remarkable that the balance sheet matrix in Table 1 effectively integrates three stand-alone balance sheets of households, firms, and banks. 
In Table 1 we use the next notations:

\begin{tabular}{|c|c|}
\hline$D_{f}$ & Deposits held by firms \\
\hline$D_{h}$ & Deposits held by households \\
\hline IN & Stock of inventories at cost \\
\hline$L_{f}$ & Loans supplied by banks to firms \\
\hline$V_{b}$ & Net wealth of banks \\
\hline$V_{f}$ & Net wealth of firms \\
\hline$V_{h}$ & Net wealth of households \\
\hline
\end{tabular}

Note that according to Godley and Lavoie (2007): "All the columns and all the rows that deal with financial assets or liabilities must sum to zero. The only row that may not sum to zero is the row dealing with inventories accumulated by the firms... All assets appear with a plus sign in the balance sheet matrix while liabilities, including net worth, are assigned a negative sign".

In Table 1 we have seven unknown variables which we should find.

\section{Financial transactions related to defaulting firms}

Further, we consider a sequence of events starting from defaults of firms through fire-sales of produced goods towards write-offs of bad loans and coverage of credit losses of banks on bad loans. Thus, we will distinguish normal and fire-sales of goods. Recall that Godley's and Lavoie's model (2007) takes into consideration only events of firms' defaults.

So, some firms make mistaken decisions about what kind of goods should be produced. As a result, the produced goods turn out not in demand and must be fire-sold at a price far lower cost. In its turn, these firms cannot repay their loans and go into default. The loans become non-performing or briefly bad. Herewith, at the moment of default, the balance sheet of defaulted firms takes the next form:

$$
I N_{b}=L_{b},
$$

where $I N_{b}$ is the stock of goods produced by defaulted firms, $L_{b}$ stands for stock of bad (non-performing) loans held by them. Thus, at the moment of default, the stock of inventories of defaulted firms is exactly equal to the stock of their bad loans. Here we assume that the defaulted firms spent all their deposits to produce goods. Firstly, the rationale for this is that the amount of unused deposits is usually substantially less than the value of inventories. Secondly, this assumption leads to a maximal estimate of time of covering losses on bad loans through fire-sales. Therefore, the less the deposits, the longer the time for the fire-sale of inventories. Also, it is easy to demonstrate that the presence of an unused deposit does not change the financial result of firms from their defaults. It remains null. However, it requires significantly complicating the model by dividing all the firms between operating and defaulted ones.

We do not distinguish whether the sale of goods is voluntary or enforced, whether the goods are pledged or not. These are only procedural aspects. Nevertheless, we assume that the defaulted firms fire-sell the goods voluntarily in order to repay their loans and in this way to partly cover credit losses of banks on their bad loans.

Thus, firms incur fire-sale losses but at the same time gain a benefit from write-offs by banks of their bad loans. Indeed, in accordance with Shubik and Wilson (1977): "The advantage of default is that it enables the borrower not to repay all that he owes". Whereas, the banks do incur merely credit losses on bad loans of defaulted firms.

Write-offs by banks of bad loans are considered to be equivalent to repurchase by defaulted firms of their bad loans with a discount. The result of that is booked as firms' income.

It should be noted that households gain a benefit from the fact that they buy goods at a price far below cost.

The financial transactions related to the aforementioned sequence starting from fire-sales of goods towards coverage of banks' losses on bad loans are presented in Table 2.

As shown in Table 2, in the long run, the firms barely contract their total assets on the value (-WO) of written-off bad loans and have zero results in profit and loss.

Recall that the firms in the model have no equities. Thus, they have no losses as a result of default. Borrowing is a risk-free deal for firms but not for banks.

It should be noted that the fact that the cost of firms' default is zero may keep banks from lending (Shubik and Wilson, 1977). 
Table 2. The financial transactions starting from fire-sales of goods towards coverage of banks' losses on bad loans (view from the defaulted firms' side)

\begin{tabular}{|c|c|c|c|c|}
\hline & \multicolumn{4}{|c|}{ Changes in the stocks of } \\
\hline & $\begin{array}{l}\text { inventories } \\
\text { (+IN) }\end{array}$ & $\begin{array}{l}\text { deposits of firms } \\
\left(+D_{f}\right)\end{array}$ & $\begin{array}{l}\text { bad loans } \\
\qquad\left(+L_{b}\right)\end{array}$ & $\begin{array}{l}\text { firms profits } \\
\left(+F_{f}\right)\end{array}$ \\
\hline $\begin{array}{l}\text { Fire-sales } \\
\text { of goods produced } \\
\text { by defaulted firms }\end{array}$ & $\begin{array}{l}-W O \\
\text { sold goods } \\
\text { at cost }\end{array}$ & $\begin{array}{l}\stackrel{+}{ }+C_{f} \\
\text { fire-sales } \\
\text { revenue }\end{array}$ & & $\begin{array}{c}-\left(W O-C_{f}\right) \\
\text { losses on } \\
\text { fire-sales }\end{array}$ \\
\hline In total & $-w o$ & $+C_{f}$ & & $-\left(W O-C_{f}\right)$ \\
\hline $\begin{array}{l}\text { Write-offs } \\
\text { of bad loans }\end{array}$ & & & $\begin{array}{c}- \text { WO } \\
\text { written-off } \\
\text { bad loans }\end{array}$ & $\begin{array}{l}+ \text { WO } \\
\text { benefit from } \\
\text { write-offs }\end{array}$ \\
\hline $\begin{array}{c}\text { Transfer } \\
\text { of fire-sales revenue } \\
\text { to banks }\end{array}$ & & $\begin{array}{l}-C_{f} \\
\text { transfer of fire-sales } \\
\text { revenue to banks }\end{array}$ & & $\begin{array}{c}-C_{f} \\
\text { expenditures } \\
\text { of firms }\end{array}$ \\
\hline In total & & $-C_{f}$ & $-w o$ & $+\left(W O-C_{f}\right)$ \\
\hline$\Sigma$ & $-w o$ & 0 & $-w o$ & 0 \\
\hline
\end{tabular}

\section{Transactions-flows matrix of the economy}

Taking into account the above, we present in Table 3 the transactions-flows matrix modified by the author as compared with the original matrix developed by Godley and Lavoie (2007). Again, in accordance with Godley and Lavoie (2007):

- "The coherence of the transactions flow matrix is built on the rule that each row and each column must sum to zero.

- The zero-sum rule for each column represents the budget constraint of each sector.

- Any transaction involving an incoming flow, the proceeds of a sale or the receipts of some monetary flow, thus takes a positive sign; a transaction involving an outgoing flow must take a negative sign".

Note that the columns entitled as "current" and "capital" in the transactions-flows matrix define the equalities for increments of profits and balance sheets correspondingly of firms and banks.

In the long run, we built a model where "the system as a whole is closed in the sense that every flow and every stock variable is logically integrated into the accounting to such a degree that the value of any one item is implied by the values of all the others taken together; this follows from the fact that every row and every column sums to zero" (Godley and Lavoie, 2007).

\section{Table 3. Modified transactions-flows matrix of the economy}

\begin{tabular}{|c|c|c|c|c|c|c|c|}
\hline & & \multirow{2}{*}{ Households } & \multicolumn{2}{|c|}{ Firms } & \multicolumn{2}{|c|}{ Banks } & \\
\hline & & & Current & Capital & Current & Capital & $\Sigma$ \\
\hline Consumption & $\begin{array}{c}\text { normal sales } \\
\text { fire-sales }\end{array}$ & $\begin{array}{l}-C_{n} \\
-C_{f}\end{array}$ & $\begin{array}{l}+C_{n} \\
+C_{f}\end{array}$ & & & & $\begin{array}{l}0 \\
0\end{array}$ \\
\hline $\begin{array}{c}\text { Transfer } \\
\text { of fire-sales revenue } \\
\text { to banks }\end{array}$ & & & $-C_{f}$ & & $+C_{f}$ & & 0 \\
\hline $\begin{array}{l}\text { Inventory } \\
\text { accumulation }\end{array}$ & & & $+\Delta I N$ & $-\Delta I N$ & & & 0 \\
\hline Wage bill & & $+W B$ & $-W B$ & & & & 0 \\
\hline Profits & & & $-F_{f}$ & $+F_{f}$ & $-F_{b}$ & $+F_{b}$ & 0 \\
\hline
\end{tabular}




\begin{tabular}{|c|c|c|c|c|c|c|c|}
\hline Interests on & $\begin{array}{l}\text { loans } \\
\text { deposits }\end{array}$ & $+I D_{h}$ & $\begin{array}{l}-I L \\
+I D_{f}\end{array}$ & & $\begin{array}{c}+I L \\
-I D_{f} \\
-I D_{h}\end{array}$ & & $\begin{array}{l}0 \\
0 \\
0\end{array}$ \\
\hline $\begin{array}{l}\text { Change } \\
\text { in the stocks of }\end{array}$ & $\begin{array}{l}\text { loans } \\
\text { deposits }\end{array}$ & $-\Delta D_{h}$ & & $\begin{array}{l}+\Delta L_{f} \\
-\Delta D_{f}\end{array}$ & & $\begin{array}{l}-\Delta L_{f} \\
+\Delta D_{h} \\
+\Delta D_{f}\end{array}$ & $\begin{array}{l}0 \\
0 \\
0\end{array}$ \\
\hline $\begin{array}{l}\text { Write-offs } \\
\text { of bad loans }\end{array}$ & & & $+W O$ & & $-W O$ & & 0 \\
\hline$\Sigma$ & & 0 & 0 & 0 & 0 & 0 & 0 \\
\hline
\end{tabular}

In the Table 2 and 3 we use the next notations:

\begin{tabular}{|c|c|}
\hline$F_{b}$ & Profits of banks \\
\hline$F_{f}$ & Profits of production firms \\
\hline$I D_{h}$ & Interests on deposits held by households \\
\hline$I D_{f}$ & Interests on deposits held by firms \\
\hline$I L$ & Interests on loans held by firms \\
\hline WB & Wage bill \\
\hline WO & Write-offs of bad loans of defaulted firms \\
\hline
\end{tabular}

\section{Mathematical model of the economy with firms' defaults}

Using both the balance sheet and the transaction-flow matrices (Tables 1 and 3) allows formulating the following mathematical model of the economy. Note that all the variables of the model are considered to depend on time, unless otherwise stipulated.

The differential equation for inventories takes the next form:

$$
\begin{aligned}
& \frac{d I N}{d t}=\quad W B-\frac{C_{n}}{1+\rho}-W O \\
& \begin{array}{cccc}
\text { Flows of: } & \begin{array}{c}
\text { produced } \\
\text { goods }
\end{array} & \begin{array}{c}
\text { normal } \\
\text { sold goods }
\end{array} & \begin{array}{c}
\text { fire-sold } \\
\text { goods }
\end{array} \\
& \text { at cost } & \text { at cost } & \text { at cost }
\end{array}
\end{aligned}
$$

where $\rho$ is price markup (Kalecki, 1971), $t$ stands for time, $\frac{d}{d t}$ is the first derivative with respect to time $t$.

We present inventories $I N$ as sum of stocks of goods being produced by means of good and bad loans:

$$
I N=I N_{g}+I N_{b},
$$

where $I N_{g}$ is the stock of goods produced by non-defaulted firms.

Taking into account (1) the stock $I N_{g}$ of goods produced by non-defaulted firms is equal to:

$$
I N_{g}=I N-L_{b} .
$$

The firms' deposits are governed by the next equation:

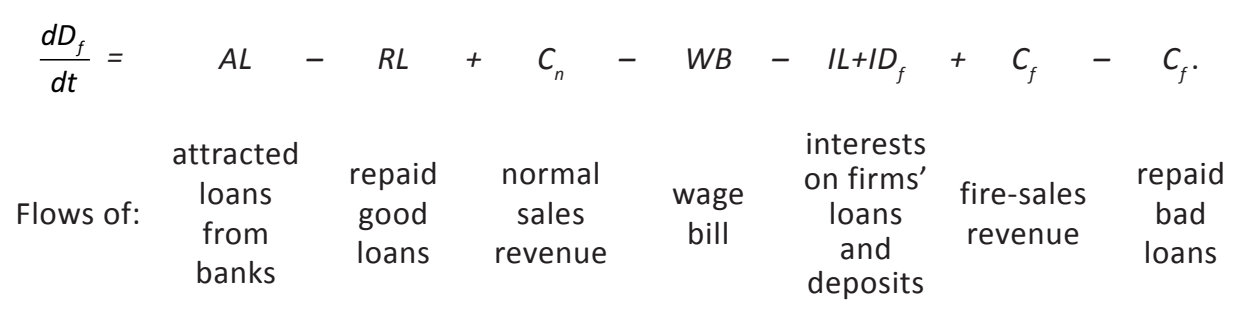


The households' deposits are ruled by the next equation:

$$
\begin{aligned}
& \frac{d D_{h}}{d t}=W B-C_{n}-C_{f}+I D_{h} . \\
& \text { consumption: } \\
& \text { Flows of: } \begin{array}{cccc}
\text { received } & \begin{array}{c}
\text { bought } \\
\text { wages } \\
\text { market } \\
\text { price }
\end{array} & \begin{array}{c}
\text { bought } \\
\text { goods at } \\
\text { fire-sale } \\
\text { price }
\end{array} & \begin{array}{c}
\text { interests } \\
\text { on }
\end{array} \\
& & \text { deposits }
\end{array}
\end{aligned}
$$

We present firms' loans as sum of good (performing) and bad (non-performing) loans:

$$
L_{f}=L_{g}+L_{b}
$$

These loans are governed by the next equations:

$$
\begin{aligned}
& \frac{d L_{g}}{d t}=\quad A L-R L-D L \text {, }
\end{aligned}
$$

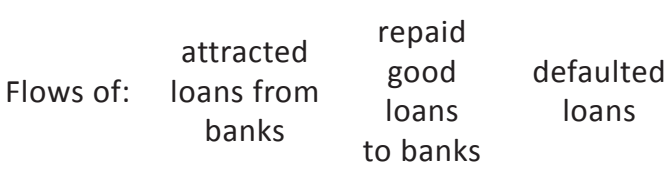

$$
\begin{aligned}
& \frac{d L_{b}}{d t}=\quad D L \quad-\quad W O . \\
& \text { Flows of: defaulted written-off }
\end{aligned}
$$

The derivatives of net wealth of households, firms, and banks are equal to their profits correspondingly. So, net wealth of households, firms, and banks are governed by the next equations:

$$
\begin{aligned}
& \frac{d V_{h}}{d t} \equiv F_{h}=\quad \frac{d D_{h}}{d t}, \\
& \text { Derivative derivative } \\
& \text { of net wealth of of deposits } \\
& \text { households of households } \\
& \frac{d V_{f}}{d t} \equiv F_{f}=\quad \frac{C_{n} \times \rho}{1+\rho} \quad-\quad I L+I D_{f}, \\
& \text { net income from interests } \\
& \text { Flows of: normal sales on loans } \\
& \text { at market price and deposits } \\
& \frac{d V_{b}}{d t} \equiv F_{b}=\quad+I L-I D_{f}-I D_{h}-\left(W O-C_{f}\right) . \\
& \text { interests losses } \\
& \text { Flows of: on loans on bad loans } \\
& \text { and deposits cut upon recovery }
\end{aligned}
$$

Into the bargain, we employ the next equation for market prices on goods (Kalecki, 1971) that are based on the cost-plus concept:

$$
p=(1+\rho) \times u c,
$$

where $\rho$ is price markup, uc is unit cost of goods. 
Equation (11) is used to convert the value of sold goods at market price into a cost price and vice versa, for instance, in order to calculate a change in inventories.

All given equations (1-10) meet both stocks and flows balances (Tables 1 and 3).

\section{Equations linking flows and stocks}

Following Keen (2010), we use the next generic equation relating the flow and stock:

Flow $=$ Rate of turnover $\times$ Stock,

where "Rate of turnover" gives the fundamental frequency of financial operation.

The collection of equations defining flows is presented in Table 4.

\section{Table 4. Equations linking flows and stocks}

\begin{tabular}{|c|c|c|}
\hline Flows & Description & Formulas \\
\hline$A L$ & Attracted firms' loans from banks & $\beta \times\left(N-L_{f}\right)$ \\
\hline$C_{f}$ & Fire-sales consumption / repayment of bad loans & $R \times W O$ \\
\hline$C_{n}$ & Normal consumption & $V_{n} \times(1+\rho) \times I N_{g}$ \\
\hline$D L$ & Defaulted loans & $p d \times L_{g}$ \\
\hline IL & Payment of interest on loans & $r_{L} \times L_{g}$ \\
\hline$I D_{f}$ & Payment of interest on firms' deposits & $r_{D} \times D_{f}$ \\
\hline$I D_{h}$ & Payment of interest on households' deposits & $r_{D} \times D_{h}$ \\
\hline$R L$ & Repayment of good loans (Keen, 2010) & $\phi_{L} \times L_{g}$ \\
\hline$W B$ & Payment of wages by firms to households (Keen, 2010) & $\phi_{D} \times D_{f}$ \\
\hline Wo & Write-offs of bad loans & $\gamma_{w o} \times L_{b}$ \\
\hline
\end{tabular}

In Table 5 we picked out notations used in the model. Presented there are the values of the model's parameters used for numerical simulation too.

Table 5. Notations and values of model's parameters

\begin{tabular}{|c|c|c|}
\hline Parameters & Description & Values \\
\hline \multicolumn{3}{|c|}{ Latin symbols } \\
\hline$N$ & Total value of loans which can be granted by banks & 100 \\
\hline pd & Probability of default of firms & $0.05 / y r$ \\
\hline$R$ & Recovery rate of bad loans & $50 \%$ \\
\hline$r_{D}$ & Annual interest rate on deposits & $15 \%$ \\
\hline$r_{L}$ & Annual interest rate on loans & $16 \%$ \\
\hline \multicolumn{3}{|c|}{ Greek symbols } \\
\hline$\beta$ & Rate of issue of loans by banks to firms & $3 / 4 y r$ \\
\hline$V_{n}$ & Rate of normal sale of goods / normal consumption & $26 / y r$ \\
\hline$V_{\text {wo }}$ & Rate of write-offs of bad loans & $1 / 7 y r$ \\
\hline$\rho$ & Price markup & $5 \%$ \\
\hline$\phi_{D}$ & Rate of payment of wages & $2 / y r$ \\
\hline$\varphi_{\mathrm{L}}$ & Rate of repayment of good loans & $1 / 7 y r$ \\
\hline
\end{tabular}


According to Keen (2010), the rate-parameters designated by the Greek symbols in Table 5 are inverse to periods of turnover. For instance, rate $\varphi_{L}$ of repayment of good loans equaled $1 / 7 \mathrm{yr}$ means that firms repay their loans every 7 years. The value of 26 for $\gamma_{n}$ corresponds to normal consumption by households having a fundamental frequency of 1 / 26th of a year, or two weeks, and so on.

\section{NUMERICAL SIMULATION}

To simulate work of the economy, we used the values of the model's parameters given in Table 5. Some results of simulation are presented on Figures 1-3.

\section{Figure 1. Dynamics of good and bad loans, and firms' deposits (developed by author)}

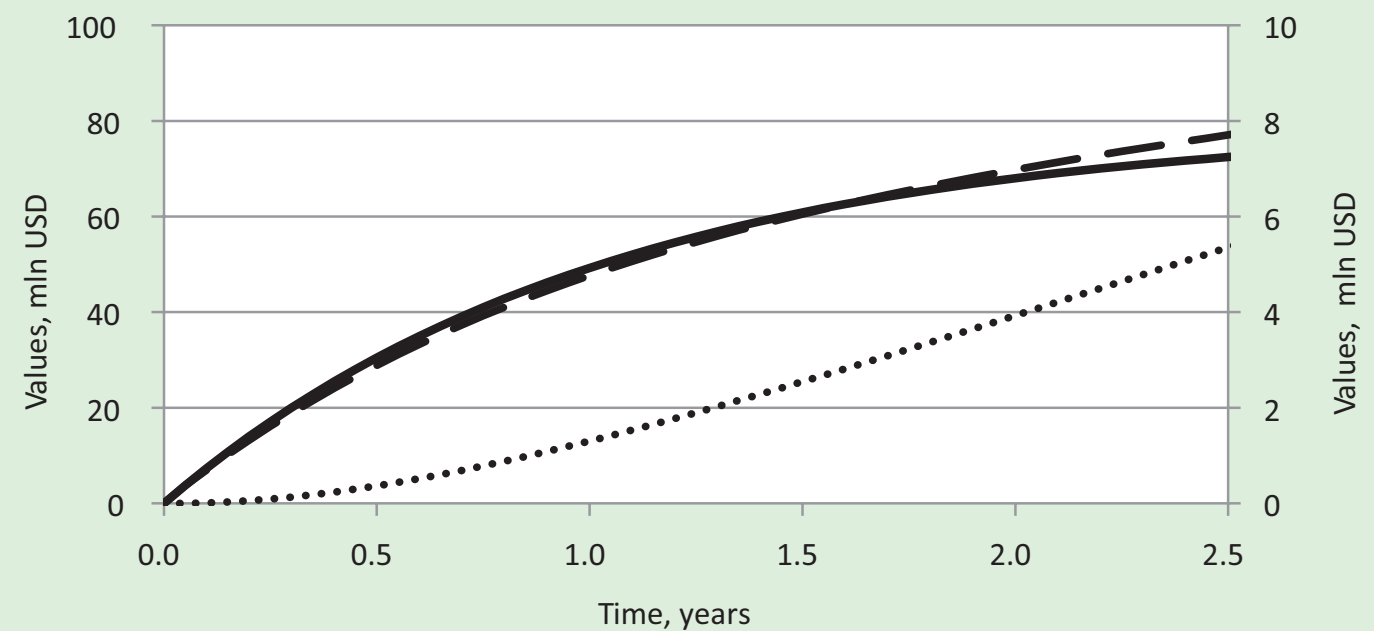

Good loans (left) $\quad$ - $\quad$ Firms' deposits (left) $\quad \ldots .$. Bad loans (right)

Figure 2. Dynamics of good and bad inventories of firms (developed by author)

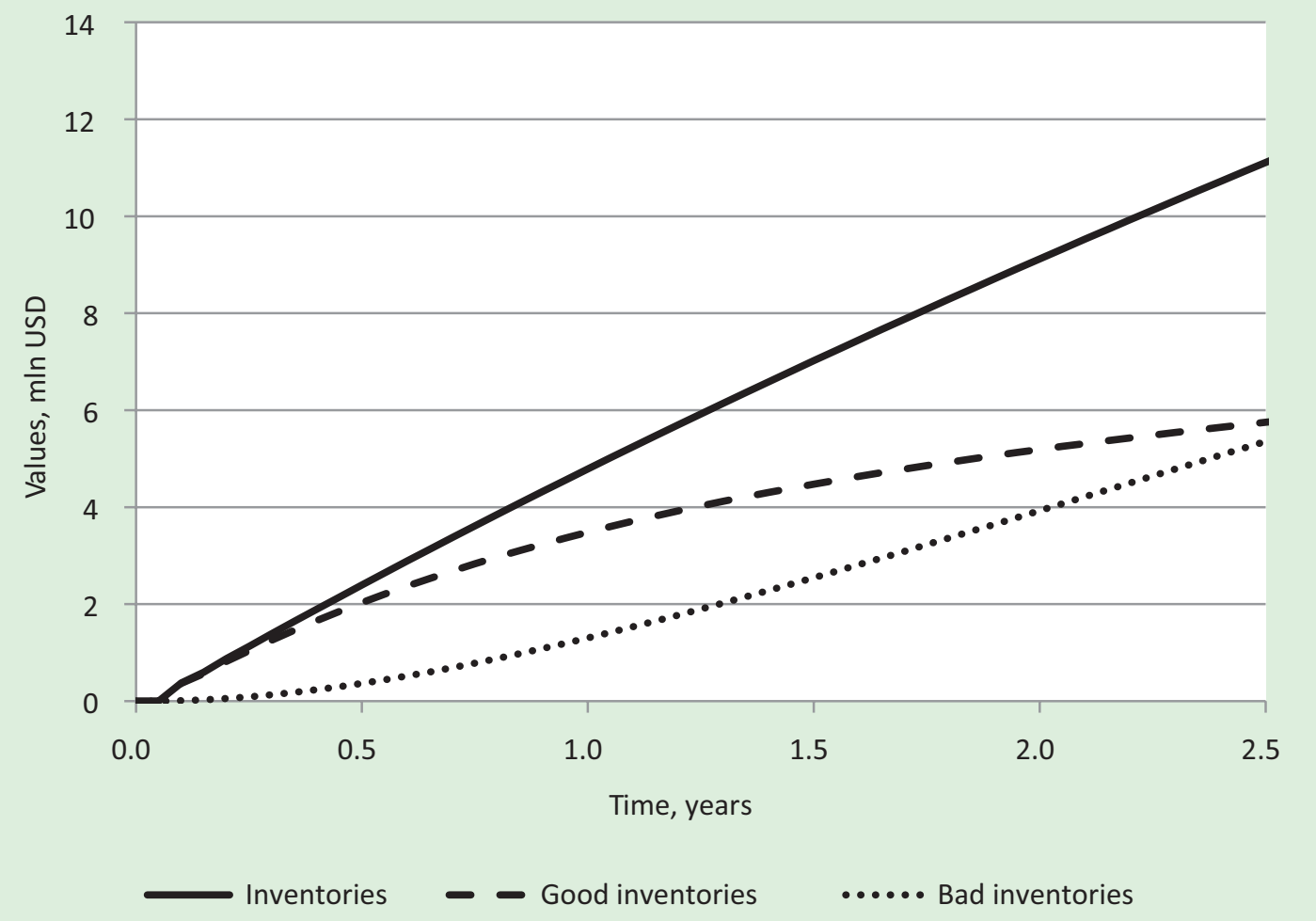


As shown in Figures 1 and 2, the defaulted firms are not in time to fire-sale goods under the model's parameters. Consequently, both the bad loans and the bad inventories are accumulated on aggregated balance sheets of firms.

\section{Figure 3. Dynamics of net wealth of households, firms, and banks (developed by author)}

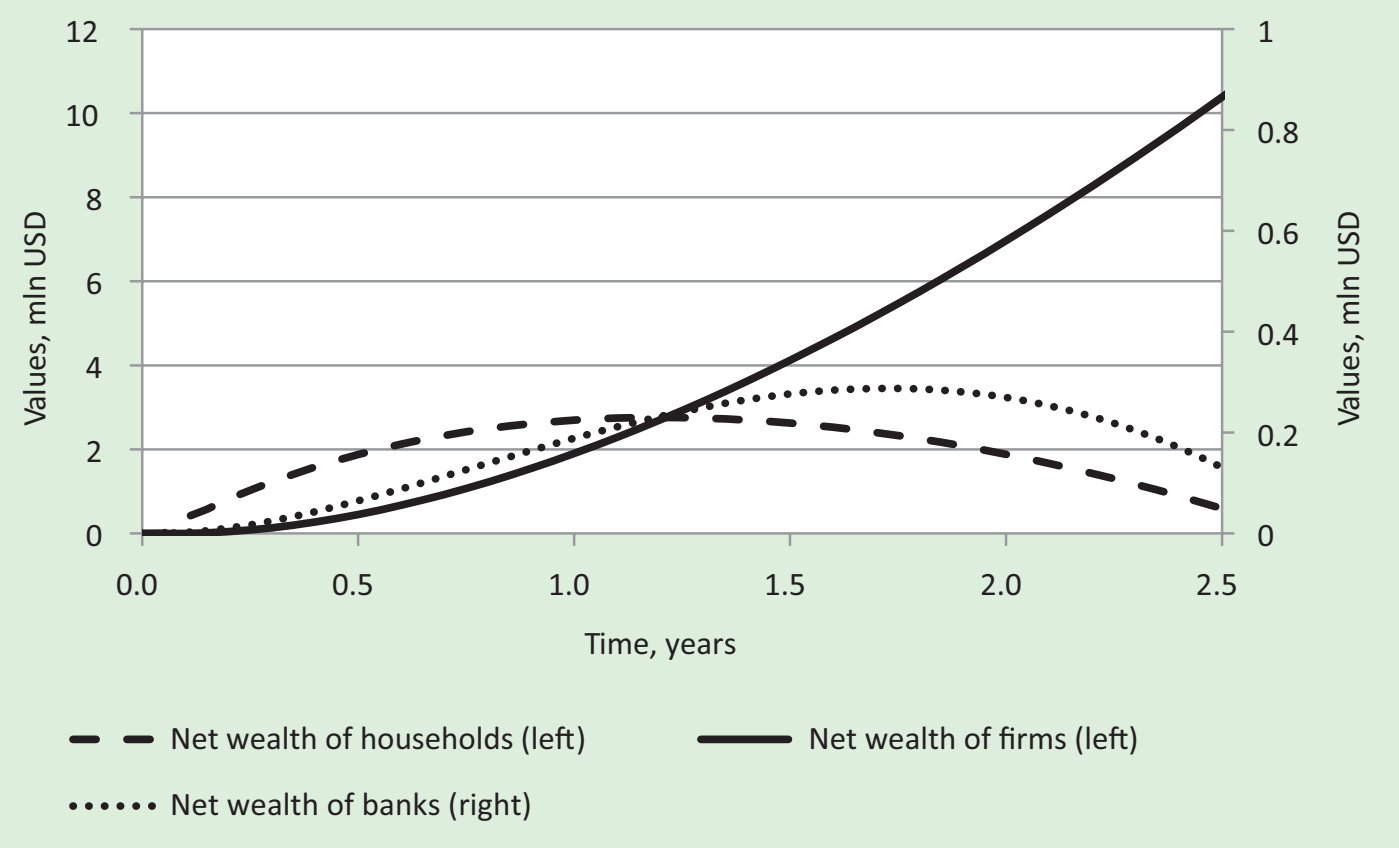

The net wealth of firms rises since the cost of default is zero, while both the net wealth of banks and households at the beginning runs high and then falls. The reasons for such behavior of the net wealth of banks and households are significantly different. The net wealth of banks begins to fall due to accumulation of credit losses on bad loans. Whereas, the net wealth of households does begin to fall due to profit paradox (Voloshyn I. and Voloshyn M., 2016), when workers of households have insufficient money in order to buy out all produced goods due to the existence of a price markup.

The balance sheet matrix of the economy at time $t=0.7$ years is presented in Table 6 .

Table 6. The balance sheet matrix of the economy at time $t=0.7$ years

\begin{tabular}{|c|c|c|c|c|}
\hline & Households & Firms & Banks & $\Sigma$ \\
\hline Inventories & & +3.37 & & +3.37 \\
\hline Deposits & +2.33 & +37.33 & -39.66 & $\mathbf{0}$ \\
\hline Loans & & -39.78 & +39.78 & $\mathbf{0}$ \\
\hline Net wealth & -2.33 & -0.92 & -0.12 & -3.37 \\
\hline$\Sigma$ & 0 & 0 & 0 & 0 \\
\hline
\end{tabular}

\section{CONCLUSIONS AND DIRECTIONS FOR FURTHER INVESTIGATION}

Sequentially examining the full chain of events starting from the default of firms through the fire-sale of goods towards writeoffs of bad loans, a new matrix of financial transactions was developed. As a result, there was an understanding of how firms' defaults affect all economic agents. It was shown that if firms have no equities, the cost of default of those firms equals zero. Indeed, firms suffer from losses on fire-sales but at the same time, they have a benefit from write-offs of their loans. Whereas, banks incur only the losses on bad loans. According to Shubik and Wilson (1977), this situation may restrain lending to the economy.

The considered matrix of financial transactions was incorporated into the transactions-flows matrix of a closed economy consisting of households, firms, and banks. The matrix obtained significantly differs from Godley's and Lavoie's matrix that the 
flows caused by write-offs of bad loans were taken to flows of incomes and expenses, not to the flows generated by changes in operating assets and liabilities.

A hallmark of the flow model is to use the assumption that normal and fire-sales consumptions depend on the rate of sales of inventories of non-defaulted and defaulted firms, respectively. While Keen's model assumes that consumption depends on the stock of deposits (Keen, 2010).

On the basis of the balance sheet and transactions-flows matrices, a mathematical model of the economy was developed. The stock-flow consistent framework used allows us to be sure that nothing will be lost neither in stocks nor in flows. Our model is rich enough to release the taken assumptions in order to bring the model closer to reality.

The model allows studying how key parameters such as the probability of default, the rate of fire-sales (newly injected parameter), recovery rate, and interest rates on loans and deposits affect the performance of banks and firms, observing economic dynamics in time. It should be noted that the mathematical model can be used in various macroeconomic models not necessarily based on the SFC framework.

Numerical simulation of the model was carried out. Under the chosen parameters of the models, the net wealth of firms rises due to the cost of default being zero, while both the net wealth of banks and households at the beginning run high and then fall. The reasons for such behavior of the net wealth are significantly different. The net wealth of banks begins to fall due to the accumulation of credit losses. Whereas, the net wealth of households begins to fall due to profit paradox (Keen, 2010), when workers of households have insufficient money in order to buy out all produced goods due to the existence of a price markup.

For further investigation, we are planning to explore the relationship between defaults of both firms and banks. In this case, we will consider that the probability of default depends on the structure of the aggregated balance sheet of firms. We will presume that interest rates on loans will be set by banks on a risk-based rule.

\section{References}

- Benes J., Kumhof M. Laxton D. (2014). Financial Crises in DSGE Models: A Prototype Model. Working Paper Series, Vol. 14, No. 57-59, IMF.

- Caiani A., Godin A., Caverzasi E., Gallegati M., Kinsella S., Stiglitz J.E. (2016). Agent Based-Stock Flow Consistent Macroeconomics: Towards a Benchmark Model. Journal of Economic Dynamics and Control, No. 69, pp. 375-408. https://doi.org/10.1016/i.jedc.2016.06.001

- Godley W. (1996). Money, finance and national income determination: An integrated approach. Working Paper, No. 167, The Levy Economics Institute of Bard College.

- Godley W., Lavoie M. (2007). Monetary Economics. An Integrated Approach to Credit, Money, Income, Production and Wealth. UK: Palgrave Macmillan. https://doi.org/10.1057/9780230626546

- Goodhart C.A.E. (2008). Money and Default. In Mathew Forstater and L. Randall Wray (eds.), Keynes for the Twenty-First Century: The continuing relevance of the General Theory. New York: Palgrave Macmillan, pp. 213-223.

- Goodhart C.A.E., Tsomocos D.P. (2011). The Role of Default in Macroeconomics, IMES Discussion Paper Series, No. 2011E-23, pp. 1-25.

- Graziani A. (2003). The Monetary Theory of Production. Cambridge, UK: Cambridge University Press, p. 176. https://doi. org/10.1017/CBO9780511493546

- Kalecki M. (1971). Selected Essays on the Dynamics of the Capitalist Economy. - Cambridge: Cambridge University Press, pp. 35-42.

- Keen S. (2010). Solving the Paradox of Monetary Profits. Economics: The Open-Access, Open-Assessment E-Journal, Vol. 4, No. 31.

- Shubik M., Wilson C. (1976). A Theory of Money and Financial Institutions. Part 30 (revised). The Optimal Bankruptcy Rule in a Trading Economy Using Fiat Money. Zeitschrift fur Nationalokonomie, Vol. 37, No. 3-4, pp. 337-354.

- Stellian R., Buitrago J.P.D. (2014). Business Bankruptcy: An Agent-Based Model, A Monetary Analysis. Seminario 372.

- Voloshyn I., Voloshyn M. (2016). The Model of Closed Economy with Full Consumption of Products. Working Paper, https://doi.org/10.13140/rg.2.1.2918.0403 
- White W.R. (2010). The Mayekawa Lecture: Some Alternative Perspectives on Macroeconomic Theory and Some Policy Implications. Monetary and Economic Studies, No. 28, Institute for Monetary and Economic Studies, Bank of Japan, pp. 35-58.

- Yamaguchi K. (2013). Money and Macroeconomic Dynamics. Accounting System Dynamics Approach. Edition 2.0. - Japan: Japan Futures Research Center. 